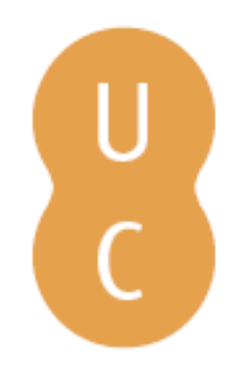

\title{
nombalina
}

\section{O tribunal de Diógenes Laércio: Platão e o plágio de Epicarmo}

\author{
Autor(es): $\quad$ Santoro, Fernando \\ Publicado por: Imprensa da Universidade de Coimbra \\ URL \\ persistente: \\ URI:http://hdl.handle.net/10316.2/34715 \\ DOI: \\ DOI:http://dx.doi.org/10.14195/978-989-721-042-6_15 \\ Accessed : $\quad$ 26-Apr-2023 12:06:07
}

A navegação consulta e descarregamento dos títulos inseridos nas Bibliotecas Digitais UC Digitalis, UC Pombalina e UC Impactum, pressupõem a aceitação plena e sem reservas dos Termos e Condições de Uso destas Bibliotecas Digitais, disponíveis em https://digitalis.uc.pt/pt-pt/termos.

Conforme exposto nos referidos Termos e Condições de Uso, o descarregamento de títulos de acesso restrito requer uma licença válida de autorização devendo o utilizador aceder ao(s) documento(s) a partir de um endereço de IP da instituição detentora da supramencionada licença.

Ao utilizador é apenas permitido o descarregamento para uso pessoal, pelo que o emprego do(s) título(s) descarregado(s) para outro fim, designadamente comercial, carece de autorização do respetivo autor ou editor da obra.

Na medida em que todas as obras da UC Digitalis se encontram protegidas pelo Código do Direito de Autor e Direitos Conexos e demais legislação aplicável, toda a cópia, parcial ou total, deste documento, nos casos em que é legalmente admitida, deverá conter ou fazer-se acompanhar por este aviso.

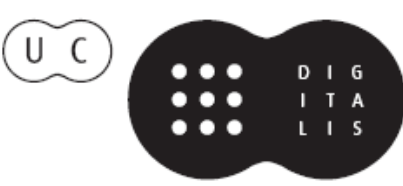




\section{Dos Homens e suas Ideias \\ Estudos sobre as Vidas de Diógenes Laércio}

Delfim Leão, Gabriele Cornelli \& Miriam C. Peixoto (coords.) 


\title{
O Tribunal de Diógenes LaÉrcio: Platão e o plágio de Epicarmo (Diogenes Laertius' tribunal: Plato and the plagiarism of Epicharm)
}

\author{
Fernando Santoro \\ Depto. de Filosofia da Universidade Federal do Rio de Janeiro
}

\begin{abstract}
Resumo: Examino um testemunho particularmente controverso dos textos do comediógrafo Epicarmo. Este testemunho refere-se a uma longa passagem sobre Platão, que começa no nono capítulo, Livro III, das Vidas e Doutrinas dos Filósofos Ilustres de Diógenes Laércio. Este testemunho traz explicitamente à tona uma situação de imitação, já que o texto é apresentado como prova em um caso de plágio. Especificamente, o caso de plágio está dentro do contexto de uma controvérsia envolvendo a fundação de um gênero que apresenta grande importância para o desenvolvimento do discurso filosófico - o diálogo socrático. A passagem referida é importante para a história da filosofia, uma vez que ajuda a reconstituir as diretrizes de Platão e do pensamento da Academia. A acusação de plágio de alguma forma evoca as discussões sobre o que Harold Cherniss chamou de "o enigma da Primeira Academia" em seu livro homônimo (1945). Outra preocupação deste estudo diz respeito aos critérios de avaliação de autenticidade na recepção filológica de Epicarmo, que aparece nas edições críticas de suas obras.
\end{abstract}

Palavras-chave: Epicarmo, Platão, plágio, Diógenes Laércio

Abstract: I would like to examine a particularly controversial testimony of the texts written by the comedy playwright Epicharmus. This testimony refers to a long passage about Plato, which begins in the ninth chapter, Book III, of Diogenes Laertius' Lives and Opinions of Eminent Philosophers. This testimony brings to light a situation about imitation, since the text is presented as evidence in a case of plagiarism. Specifically, the case of plagiarism lies within the context of a classic controversy involving the foundation of a genre which presents great importance for the development of philosophical discourse - the Socratic dialogue. The referred passage is important for the history of philosophy as it helps to reconstitute the guidelines of Plato and the Academy's thinking. A charge of plagiarism somehow evokes the discussions on what Harold Cherniss called "The riddle of the early Academy" in his homonymous book (1945). I will also be concerned with the evaluating criteria of authenticity in the philological reception of Epicharmus, which appears in the critical editions of his works. Key-words: Epicharmus , Plato, plagiarism, Diogenes Laertius

\footnotetext{
${ }^{1}$ Agradeço as excelentes contribuições de Livio Rossetti e Luc Brisson, com quem pude discutir e melhorar vários pontos deste texto, por ocasião de nossos encontros nos Seminários Archai, em Brasília e Eleia. Agradeço também a Gabriele Cornelli, sem o qual estes encontros não existiriam. Pesquisa realizada no âmbito do acordo de cooperação Capes/Cofecub "As Origens da Linguagem Filosófica: Estratégias retóricas e poéticas da sabedoria antiga.”
} 
Examinarei um testemunho particularmente controverso da recepção dos textos do comediógrafo Epicarmo, que como se sabe, é também um dos mais antigos pensadores associados ao círculo dos pitagóricos. Trata-se de uma extensa passagem sobre Platão, no capítulo nove do terceiro livro das Vidas e doutrinas dos filósofos ilustres de Diógenes Laércio, em que este transforma o filósofo em réu de um tribunal, para apresentar as suas influências doutrinais. $\mathrm{O}$ testemunho nos interessa por várias razões de ordem histórica, filológica e filosófica que compõem o caráter vivo dessa obra que mescla propositalmente fatos da vida dos filósofos com suas próprias teorias. Primeiro, pelo fato de trazer explicitamente uma situação que envolve a questão da imitação, que Platão assim como os pitagóricos punham no centro de suas doutrinas; visto que o texto é apresentado em testemunho e prova acusatória de um caso de plágio. Do ponto de vista histórico, o caso de plágio está inserido no contexto de uma controvérsia clássica envolvendo a constituição de um gênero literário de suma importância para a elaboração do discurso filosófico - o Diálogo Socrático - para o qual Livio Rossetti nos tem chamado bastante a atenção nos últimos anos, e particularmente no seu último livro homônimo (2011). A dita passagem também é importante deste ponto de vista, para a reconstituição das linhas mestras do pensamento de Platão e da Academia, especialmente no que concerne as suas fontes itálicas. De algum modo, esta acusação nos leva para as discussões acerca do que Harold Cherniss, no livro homônimo (1945), intitulou de "Enigma da Antiga Academia". Também nos interessa a avaliação dos critérios de autenticidade presentes na recepção filológica de Epicarmo em suas edições críticas; discussão para a qual muito tem contribuído Omar Álvarez e sem a qual não se pode julgar a acusação de plágio dirigida a Platão.

Situemos o contexto da passagem. Diógenes Laércio propõe compreender a filosofia de Platão como uma filosofia mista; qualificação que Nietzsche retomará quando for contrapor essa filosofia mista de Platão às filosofias não mistas ou puras dos filósofos pré-platônicos, no seu opúsculo sobre Os filósofos na idade trágica dos gregos (1873). Os elementos dessa mistura platônica são três, segundo Diógenes: as considerações sobre os entes sensíveis, a partir de Heráclito; dos inteligíveis, segundo Pitágoras; e sobre as questões políticas, segundo Sócrates ${ }^{2}$.

Diógenes segue expondo, em primeiro lugar, o modo como Platão entrou em contato com os ensinamentos de Pitágoras: conforme o testemunho de um biógrafo peripatético chamado Sátiro, ele teria primeiro encomendando ao amigo Díon da Sicília que comprasse de Filolau três livros pitagóricos (3.9).

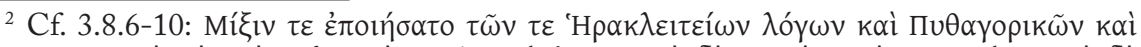

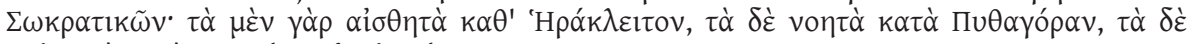

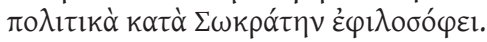


Em seguida, Diógenes cita Álcimo, um orador e historiador do final do quarto século antes de Cristo, discípulo de Estílpon, que teria dito, em um livro de acusação Contra Amintas, que Platão se aproveitou e transcreveu várias obras de Epicarmo ${ }^{3}$. Diógenes passa então a citar diretamente a acusação de plágio formulada por Álcimo:

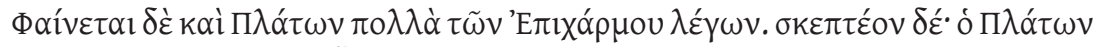

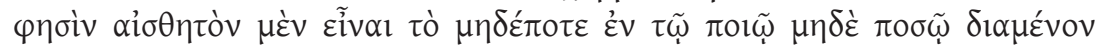

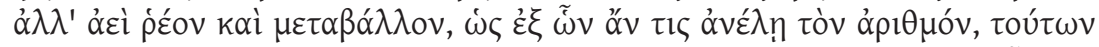

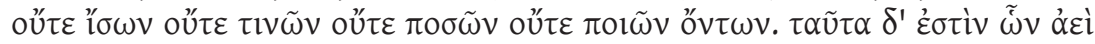

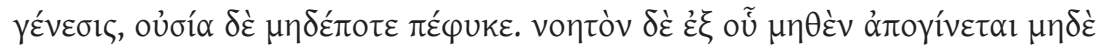

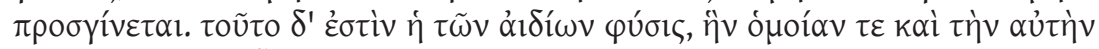

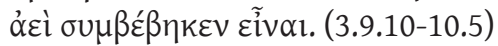

Parece que Platão disse muitas coisas a partir de Epicarmo. Examinemos: Platão disse que o sensível é o que nunca permanece em qualidade nem em quantidade, mas sempre flui e se transforma, de modo que se alguém privasse tais coisas do número, nem a identidade nem a quididade nem a quantidade nem a qualidade destas existiriam. Tais coisas têm sempre devir, e naturalmente nenhuma essência. Já o inteligível é o de que nada se retira nem se acrescenta. Esta é a natureza das coisas eternas, que é sempre semelhante e sempre coincide consigo.

Álcimo começa por resumir a teoria platônica sobre a natureza do sensível e do inteligível, em que o número aparece como a essência permanente das coisas e a natureza do que é eterno. Logo em seguida, para que se compare com tais doutrinas expressas por Platão, é a vez de Álcimo fazer uma citação, desta vez daquilo que diz Epicarmo a respeito do sensível e do inteligível ( $\kappa \propto i$

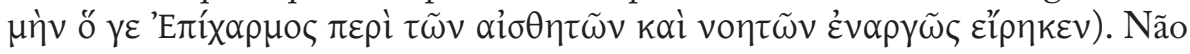
deixemos de reparar que as citações, estas e as seguintes, virão em versos, 41 versos repartidos entre tetrâmetros trocaicos e trímetros iâmbicos. Reparemos ainda que as duas primeiras aparecem no formato de um diálogo cômico ${ }^{4}$ :

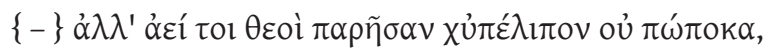

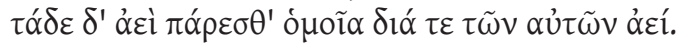

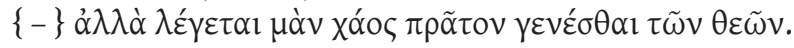

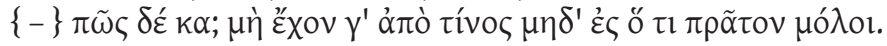

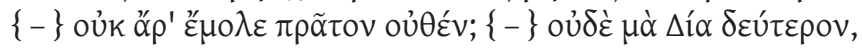

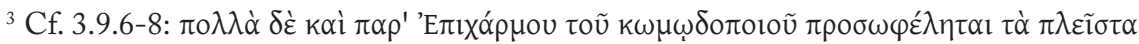

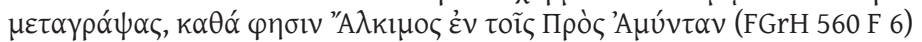
32.

${ }^{4}$ Para um exame detalhado da forma dialogal dessas duas citações, cf. Álvarez Salas 2007c
} 


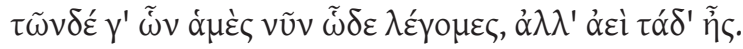

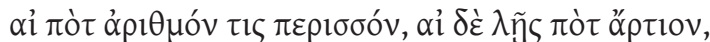

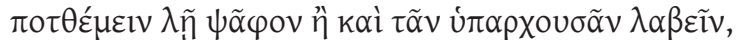

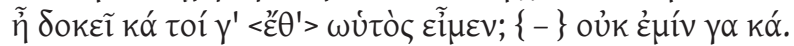

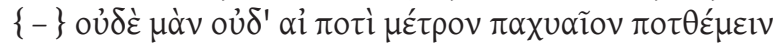

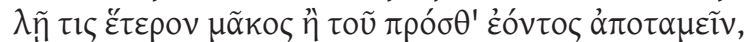

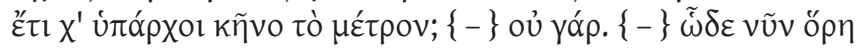

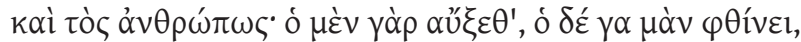

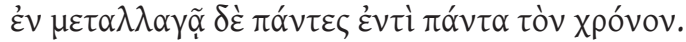

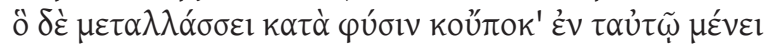

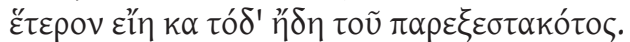

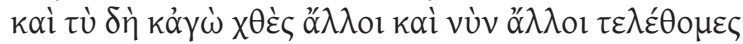

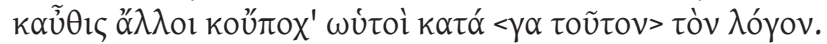
$(3.10 .7-11.13=23 \mathrm{~B} 1,2 \mathrm{DK})$

- Mas os deuses sempre permaneciam presentes, nunca sumiam; e seus atributos sempre eram semelhantes porque dos mesmos sempre.

- Mas dizem que o caos gerou-se antes dos deuses.

- Como assim? Nem pode, pois se não há nada nem de que nem para que algo venha em primeiro!

— Então nada veio em primeiro? — Nem em segundo, por Zeus! Nenhuma das coisas de que agora falamos; pois que são sempre!

$*$

Pegue um número impar, ou par, se preferes! Acrescenta ou retira uma unidade, achas que ainda é o mesmo? - Por mim é que não!

- Claro que não! Se ainda pegardes uma braça

e acrescentares ou retirares uma medida diferente, ainda iremos supor que temos a mesma medida? - Não.

- Pois agora veja o homem: enquanto que um cresce, o outro míngua, ambos estão o tempo todo em transformação.

$\mathrm{E}$ o que se transforma por natureza nunca permanece em si mesmo, sendo já outro do que o que ele se alterou.

Assim, tu e eu, ontem éramos outros do que agora, e seremos ainda outros; nunca seremos os mesmos pela mesma razão.

Álcimo, depois desta citação, retoma a sua recensão da teoria platônica

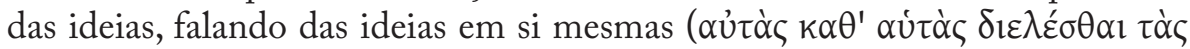

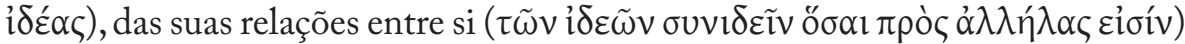
e da sua participação nas coisas que recebem os mesmos nomes que elas ( $\grave{\alpha}$

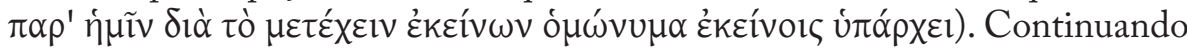
a comparação, volta a citar o que diz Epicarmo sobre o bem e as ideias:

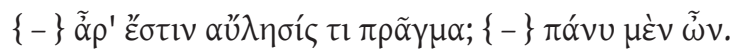




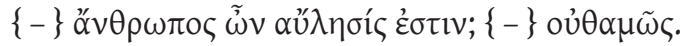

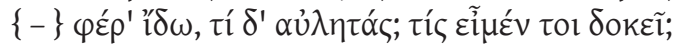

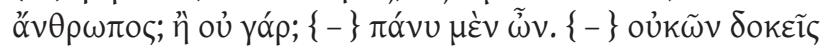

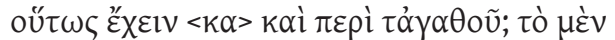

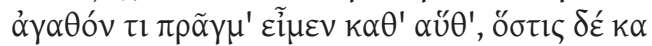

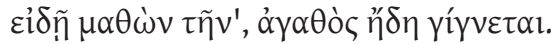

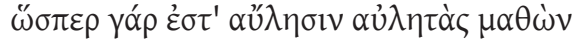

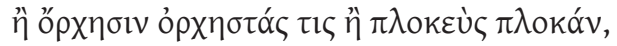

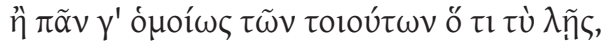

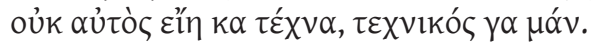

$(3.14 .1-14.11=23 \mathrm{~B} 3 \mathrm{DK})$

- Acaso a aulética é uma realidade? - Claro que sim!

- A aulética é um homem? - De modo algum!

- Vejamos, então, o que é um flautista? Quem você acha que ele é?

Um homem? Sim ou não? — Sim, claro. - Não te parece que é assim também com respeito ao bem?

Pois o bem é uma realidade por si, e quem soubesse aprendendo, bom se tornaria. Como é aprendendo a tocar flauta que alguém se torna flautista, ou dançando, que alguém se torna dançarino, ou tecendo, um tecelão.

$\mathrm{E}$ assim para qualquer outro exemplo semelhante que tomares, ele não seria a própria arte, mas sim o artífice.

Álcimo não para por aqui. Agora é a vez de apresentar a teoria platônica do conhecimento, que envolve as doutrinas da imortalidade da alma e da anamnese. Desta vez, porém, ele não vai apenas resumir e aludir às teorias e opiniões platônicas, mas também vai citar o filósofo. A citação, todavia, não remete a nenhum dos diálogos conhecidos, mas a uma "consideração acerca das ideias". Tampouco reconhecemos a passagem citada em algum dos textos conhecidos de Platão, nem ao menos no diálogo Parmênides ${ }^{5}$, que recebia nas tetralogias o subtítulo de Acerca das ideias. Teria existido algum tratado platônico com este título? Ele não consta nas listas do próprio Diógenes Laércio, a não ser como o dito subtítulo. Para Platão, temos a sorte, pouco frequente para os antigos, de conhecer e possuir a integralidade do que ele escreveu em vistas de publicação. Por outro lado, consta não apenas na lista de Diógenes, mas também em várias outras listas do período helenístico, a referência ao título Acerca das Ideias, atribuído a Aristóteles. Tratado o qual, se confiarmos nos trechos transcritos por Alexandre em seu comentário à Metafísica de Aristóteles, discutia vários pontos do conteúdo da teoria platônica das ideias, particularmente alguns problemas que aparecem no diálogo Parmênides.

${ }^{5}$ Luc Brisson remete a passagem a Fédon 96b e Parmênides 128e; mas sua remissão não é à identidade textual e sim a alguma semelhança no conteúdo. Cf. Goulet-Cazé 1999429 n. 6. 
Conteúdo que reencontramos nesta e também nas outras referências de Álcimo às doutrinas que Platão teria plagiado de Epicarmo. Não será a primeira vez que comentadores peripatéticos confundem obras de Platão e Aristóteles, visto que este escrevia sistematicamente comentários aos textos do mestre, com títulos próximos ${ }^{6}$. Acredito que este não é um dado irrelevante para a nossa consideração. Luc Brisson ${ }^{7}$ traduziu e discutiu a passagem, no contexto do polêmico dossiê acerca das doutrinas não escritas (agrapha dogmata) de Platão e, com razões suplementares, também atribui a Aristóteles a base sobre a qual os historiadores helenistas acusaram Platão de plagiar os pitagóricos. Segundo ele, Aristóteles em momento algum aludiu a qualquer plágio, mas no primeiro livro da Metafísica, ao falar das influências que recebeu Platão, cita justamente os pitagóricos, Heráclito e Sócrates. Passagem bem conhecida dos filósofos e historiadores helenistas, cuja ideia, como vimos acima, Diógenes encampou completamente quando disse que Platão era um filósofo misto. Vejamos a passagem de Aristóteles.

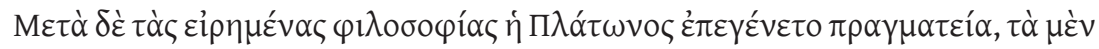

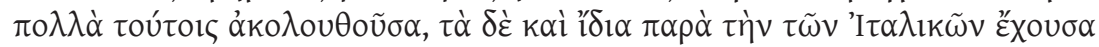

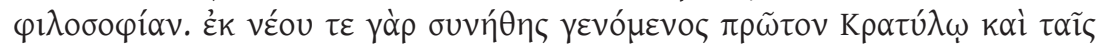

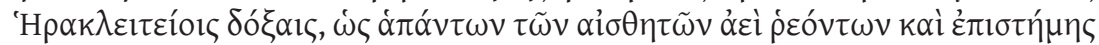

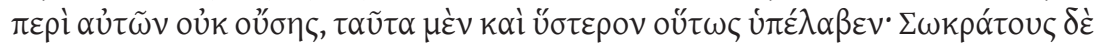

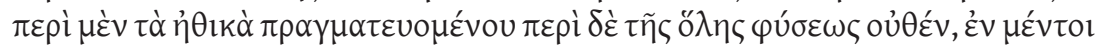

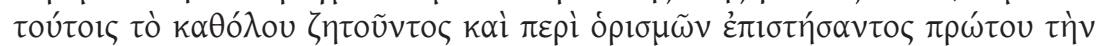

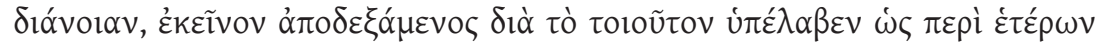

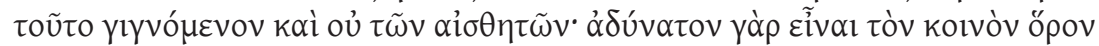

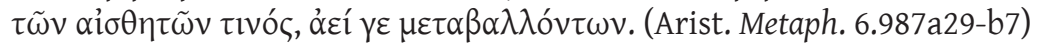

Depois das filosofias de que falamos surgiu a realizada por Platão, a qual, se acompanha estes [os pitagóricos] em muitas coisas, também tem coisas próprias ao largo da filosofia dos itálicos. Pois desde jovem, ele primeiro veio a ser frequentador de Crátilo e das opiniões heraclíticas, segundo as quais tudo o que é sensível sempre flui e não pode haver ciência destas; o que continuou sustentando também mais tarde. Por outro lado, recebeu as demonstrações de Sócrates que, tendo tratado de assuntos éticos mas nada a respeito da natureza como um todo, nestes buscou o universal e foi o primeiro a investigar com o pensamento suas definições [...]

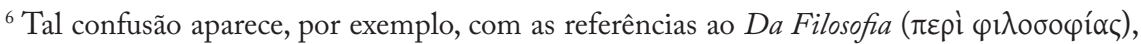
que Aristóteles atribui a Platão (De Anima 404b18) e Temístio remete a Aristóteles; Simplício

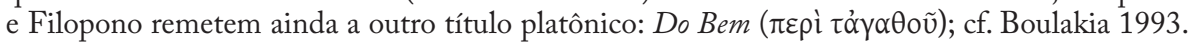
Para os títulos aristotélicos de comentários a Platão, cf. o índice de Ross 1979.

${ }^{7}$ Brisson 1992 e "Diogène Laërce, 'Vies et doctrines des philosophes illustres', Livre III : Structure et contenu" in : Aufstieg und Niedergang der Römischen Welt (ANRW) e (1993) "Les attaques de plagiat lancées contre platon.” In: Dixsaut, Monique, Contre Platon, p.352. 
Parece-me claro que o conhecimento de Platão exposto por Álcimo, assim como o de Diógenes Laércio, tem uma clara matriz aristotélica, ou pelo menos provém das discussões da Academia do tempo em que Aristóteles a frequentava. Pois bem, depois de ter citado este Platão de clara matriz aristotélica, Álcimo volta a citar outras passagens de Epicarmo de onde Platão teria extraído essas doutrinas. Agora não temos um diálogo cômico, como nas demais citações, mas versos que lembram mais o canto coral de uma comédia:

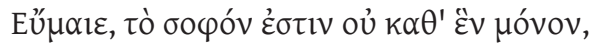

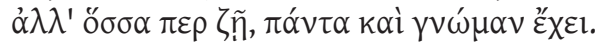

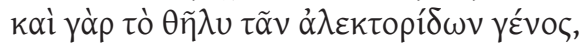

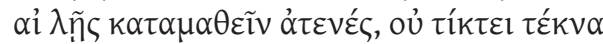

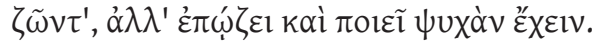

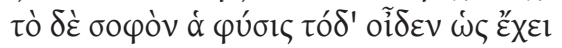

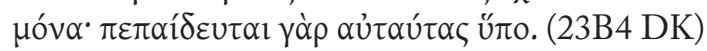

Eumeu, o saber não é somente para um, mas enquanto vive, tudo tem pensamento. Pois a fêmea da raça galinácea, Se observares com atenção, não pare pintos vivinhos, mas choca os ovos para dar-lhes vida. Tal saber a natureza é que sabe manter sozinha: pois ela aprendeu consigo mesma.

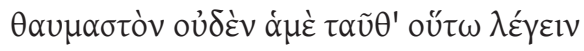

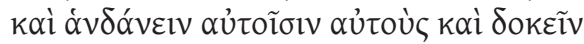

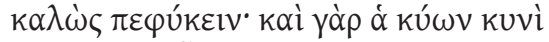

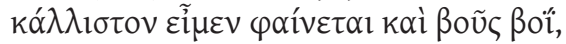

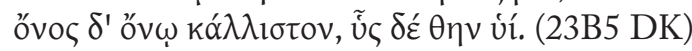

Nada espantoso que nós assim falemos e regozijemos de nós e nos orgulhemos naturalmente de nós mesmos; também para o cão nada mais belo que o cão, e assim o boi parece ao boi, para o asno o asno é lindo, para o porco o porco é mais.

Para coroar a longa passagem acusatória de Álcimo, que perpassa oito capítulos do livro sobre Platão e comporta quatro citações das comédias de Epicarmo, num total de 41 versos, Diógenes Laércio, por sua conta, acrescenta um trecho a mais, provavelmente extraído de uma parábase das comédias de Epicarmo, em que, vangloriando-se, o comediógrafo previu que seria emulado no futuro: 


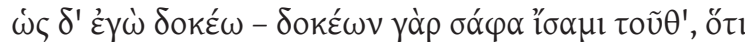

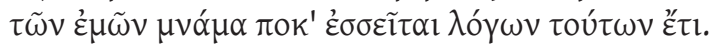

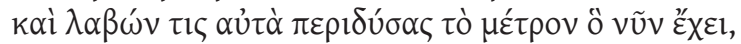

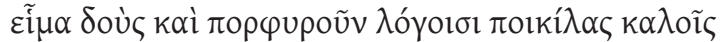

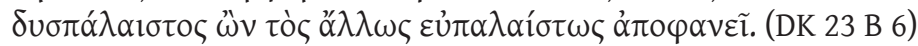

Assim penso eu - e penso que sei com clareza, Destas minhas palavras ainda vão se lembrar.

Alguém as tomará e as despojará de seu metro atual, Vestindo-as de púrpura e de belas palavras coloridas Astucioso, fará os outros parecerem ingênuos.

Visto o texto da acusação, passemos às considerações que nos interessam. Primeiro no que se refere às possíveis contribuições de Epicarmo para a gênese desse gênero literário que Livio Rossetti se não batizou, com certeza consagrou em sua importância para o estudo das origens da filosofia: o Diálogo Socrático. Em seu livro homônimo (2011 40-41), Rossetti inclui as passagens de Diógenes sobre o plágio de Epicarmo entre os elementos textuais do dossiê acerca das possíveis origens deste gênero multiplicado pelos discípulos de Sócrates e coroado por Platão. Epicarmo entra no exame dos possíveis modelos disponíveis à época. Mas pleiteio que Rossetti não descarte tão rapidamente sua hipótese de que as comédias de Epicarmo tenham contribuído como um dos modelos para a constituição do gênero. Os modelos da comédia não retiram a originalidade do Diálogo Socrático, mas certamente forneceram ingredientes importantes para a elaboração da nova receita. Os dois contra-argumentos de Rossetti são verdadeiros, mas, a meu ver, não deveriam dar cabo de todo o alcance de sua própria hipótese. O primeiro contra-argumento aponta que os pontos de contato entre os testemunhos de Epicarmo e Platão ali apresentados são doutrinais e, portanto, estranhos ao agenciamento discursivo que caracteriza o gênero: "Il s'agit de points de contact de caractère doctrinal (qui relèvent du contenu) et donc étrangers à l'agencement des logoi (une formule, une stratégie de communication)." O segundo, que Epicarmo seria relativamente distante da época de proliferação do Diálogo Socrático: "Épicharme appartient à une époque relativement lointaine."

Sem dúvida a atenção de Álcimo, bem como a de Diógenes, na antiguidade, e de leitores contemporâneos como Brisson, está voltada para as semelhanças de caráter doutrinal. Mas os exemplos citados mostram mais do que isso, mostram também semelhanças do ponto de vista discursivo, mesmo se os logoi socráticos são em prosa e não em verso, como nas comédias. Não me refiro às passagens que atribuímos ao coro. Mas sem dúvida são semelhantes as partes dramáticas, que envolvem algum diálogo, citadas nas seções 10,11 e 14. É evidente a semelhança com a estratégia do discurso curto de Sócrates (a 
braquilogia) composto de sequências argumentativas de perguntas e respostas. Neste sentido, podemos entender que o discurso epicármeo incorpora e já dá um passo além do que tinha alcançado a lógica argumentativa itálica de seu tempo, anunciando e aproximando-se da dialética socrática. Além disso, podemos apontar outros detalhes de estilo, tais como a resposta jocosa

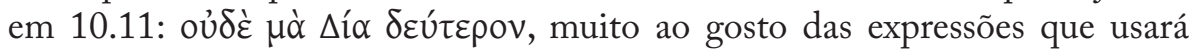
Platão para compor o caráter irônico de Sócrates. Apontemos também o uso de silogismos paradoxais, tal como, em 11.7-13, o uso do chamado

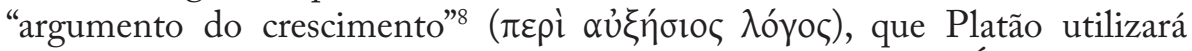
para expor a doutrina heraclítica do devir, no Teeteto (152d-e). É possível que esse argumento também fosse um desdobramento, ou uma versão aplicada ao problema da transformação, de outro famoso argumento de proveniência pitagórica, chamado de 'argumento do grande e do pequeno', nomeado ainda pela expressão mais esotérica e quase blasfema de 'díada indeterminada'. Esses argumentos paradoxais e seus nomes obtusos serão abundantemente utilizados nas comédias para retratar Sócrates, tal como o chamado 'argumento do mais fraco' que aparece nas Nuvens de Aristófanes e também na Apologia (19b) e no primeiro livro da República de Platão. Parece que tais argumentos fizeram alargar a fama de não poucos oradores deste período, quando não ganharam fama própria eles mesmos - os argumentos - independente de seus criadores.

Contudo é, com clareza, na citação da seção 14 que veremos um discurso de Epicarmo com estilo idêntico à maneira de Platão retratar as argumentações epagógicas ou indutivas de Sócrates. A mesma escolha de exemplos simples nas atividades artísticas, tais como a aulética, a arte da dança, a tecelagem, usados para alcançar reflexões sobre coisas mais abstratas, tais como 'o bem em si mesmo'.

Estes não são apenas elementos doutrinais e certamente fazem parte do agenciamento dos discursos socráticos, de modo que não seria inútil buscar em expressões e estratégias retóricas próprias do drama cômico alguns elementos importantes na constituição do Diálogo Socrático e, consequentemente, da própria filosofia, seja em Platão seja nos demais praticantes do gênero. Claro que Rossetti continua tendo razão quanto à originalidade inventiva do Diálogo Socrático, sem o qual a filosofia não ganharia a espantosa proliferação na Grécia na passagem do quinto para o quarto século, mas a pitta não teria o mesmo sabor sem o azeite e o tomate da comédia itálica.

A segunda razão apresentada por Rossetti também é verdadeira, mas não creio que a distância de Epicarmo no passado seja um impedimento insuperável para que exerça, talvez não apenas de forma direta, uma influência nos discursos de Sócrates e também nos Diálogos Socráticos escritos por

\footnotetext{
${ }^{8}$ Cf. Álvarez Salas 200979 ss.
} 
seus discípulos. Uma influência de ingredientes retóricos e de certo espírito invectivo, que certamente deixou mais temperado o novo gênero inspirado por Sócrates. E quem os usasse menos, como Xenofonte, acabava obtendo resultados insípidos. Os textos de Epicarmo deviam estar disponíveis no quinto século em Atenas como os demais textos de origem itálica; por que não disporiam de textos dele tanto como os de Parmênides e Xenófanes? Os textos dramáticos das tragédias e, acredito eu, mais ainda os das comédias dariam bons modelos para a dramatização das conversas de Sócrates com os seus concidadãos. Afinal, não foram as comédias mesmas os primeiros lugares textuais em que Sócrates foi representado? Claro, o Sócrates das comédias e o dos Diálogos não deixam de ser diferentes, porque os gêneros são parentes mas não são o mesmo - a comédia realça a invectiva, a perplexidade, a ironia, mas nunca vai se importar com o domínio, o rigor e a medida com que Sócrates conduz a vida e consequentemente os discursos.

Por outro lado, é possível que a influência na retórica socrática da comédia itálica tenha chegado também por vias indiretas, tal como pelos ensinamentos retóricos de Górgias de Leontinos, que dizia que "é necessário desfazer a seriedade dos oponentes com ironia e a gaiatice com seriedade." ( $\tau \dot{\eta} \nu \mu \grave{\varepsilon} v$

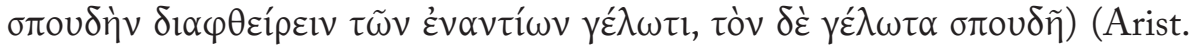
Rh. 3.1419b3). Assim, é bem provável que Platão tenha utilizado modelos retóricos oriundos da comédia, e o fato de não serem da comédia que lhe era contemporânea e mais próxima talvez até o tenha deixado mais à vontade para copiar sem que o acusassem imediatamente de plágio.

Permitam-me assim acrescentar à proveniência itálica para a constituição dos diálogos de Platão, não apenas certos conteúdos doutrinais como as teorias dos entes eternos e imutáveis de índole pitagórica, mas também certas formas retóricas e certos gêneros discursivos. Particularmente, quanto à contribuição para a dramaticidade dos diálogos, acrescentemos esta vertente de caráter cômico, que passa pela comédia de Epicarmo, e que, seguindo contra a corrente, pode ainda nos levar a outras praias mediterrâneas, tais como as Sátiras de Xenófanes de Cólofon. Diógenes Laércio nos inspira a experimentar estas linhagens travessas, e a pensar que a filosofia não se cria e cresce e se transmite apenas por discípulos disciplinados e obedientes, mas também pela invectiva, pela crítica, pelo confronto em torno de temas e questões idênticas ou pelo menos afins, prática que os comediógrafos aproveitaram, intensificaram, refinaram e difundiram.

Assim, também quando voltamos a considerar as acusações contra o plágio de Platão, estas parecem se inserir nesse modo agonístico com que os

\footnotetext{
${ }^{9}$ Em 423, As Nuvens de Aristófanes e Connos de Amípsias; em 421, Os Aduladores de Eupolis.
} 
gregos tratavam as questões de importância filosófica e, particularmente, os estudos sobre a transmissão das filosofias. Mas afinal, é possível ser aprendiz e discípulo sem, de algum modo, emular os mestres? Qual o teor da acusação de plágio levantada por Álcimo e transmitida por Diógenes? Platão teria abusado dos direitos autorais da comédia arcaica ou, filósofo misto, seria um grande, certamente o maior sábio cozinheiro, usando e abusando dos ingredientes dessas filosofias puras e desses condimentos literários que ele põe magistralmente na voz de suas personagens?

É preciso examinar um pouco mais a consistência da acusação. Que ela seja plausível não quer dizer ainda que seja verdadeira. Se observarmos o ponto de vista filológico adotado por Kassel e Austin nos Poetae Comici Greci, que reúne todas as citações de Álcimo e Diógenes na sessão dos pseudepicharmea, veremos que estes autores tendem a desacreditar a acusação, com o argumento de que as passagens de Epicarmo seriam espúrias e forjadas; de modo que seria Álcimo o plagiário e não Platão. Mas Kassel e Austin não são particularmente cuidadosos com estes fragmentos, visto que nem sequer diferenciam a citação que Diógenes acrescenta e que não poderiam atribuir ao suposto plágio de Álcimo (ex Álcimo) como o fazem ( $P C G, \mathrm{I} 164)$. Parece que o pressuposto com relação às autoridades filosóficas os teria enganado, e houveram confiado mais na idoneidade metafísica de Platão que nas intenções litigantes de Diógenes e suas fontes.

Omar Álvarez (2007a), por outro lado, é de opinião contrária e, a nosso ver, bem mais consistente, não exatamente quanto ao teor da acusação, mas à autenticidade das passagens de Epicarmo. Álvarez analisa as formas dialetais, os metros e também a transmissão do famoso 'argumento do crescimento'. Em vista dessas evidências, não vê por que pôr em dúvida a autoria epicármea dos mesmos. Além de assentir com tais evidências, gostaria de acrescentar um argumento quanto ao aspecto da poética cômica relacionado às partes da encenação. As três primeiras citações são trechos de episódios dramáticos, depois as outras duas são trechos de interlúdios corais e a última, acrescentada por Diógenes, é uma parte típica de parábase; de modo que todas as citações se encaixariam perfeitamente dentro das estruturas de composições cômicas. Assim, todas as evidências contam a favor da autenticidade, ao passo que a única autoridade contrária é que apresenta falha na instrução do caso.

Mas que as passagens de Epicarmo sejam autênticas, isso ainda não garante que a acusação de Álcimo seja procedente. Primeiro porque, como vimos, a fonte do conteúdo doutrinário provém mais das leituras acadêmicas e aristotélicas de Platão do que dos próprios diálogos do filósofo. Segundo, porque mesmo nas partes de diálogo cômico, onde o estilo do comediógrafo se assemelha à dialética de Sócrates nos diálogos platônicos, não podemos dizer que seja uma cópia realizada por Platão; visto que se trata muito mais de uma forma retórica genérica, que vai caracterizar a dialética socrática e, 
consequentemente, todo o gênero dos chamados 'diálogos socráticos'.

Segundo o ponto de vista doutrinal, Álcimo não forja as passagens de Epicarmo. Por outro lado, claramente a leitura de Platão que ele usa para a comparação é uma leitura indireta, esta sim construída conforme o pressuposto aristotélico de que a influência do pitagorismo é decisiva para a teoria das ideias de Platão. Neste caso o que interpretar? Trata-se de Platão influenciado pelos pitagóricos ou trata-se de uma leitura pitagorizante de Platão? A qual, obviamente, vai encontrar aquilo que ela mesma pôs: as semelhanças com os pitagóricos! A resposta não é tão simples, pois envolve a compreensão que os próprios antigos faziam de suas linhagens e da transmissão das ideias e doutrinas. Por mais que Álcimo seja claramente influenciado pelas leituras peripatéticas, Aristóteles não inventa nem afirma nenhum absurdo quando remonta Platão a linhagens pitagóricas. Mesmo assim, no plano doutrinal, trata-se menos de um caso de plágio do que de influência, como aponta o próprio Aristóteles no primeiro livro da sua Metafísica. E de uma influência que, ainda segundo Aristóteles, vai misturar-se com outras duas fontes filosóficas antes de resultar na composição propriamente platônica.

Do ponto de vista formal, a semelhança retórica também resulta, a meu ver, menos de um caso de plágio entre Platão e Epicarmo, do que de influência das estratégias poéticas e retóricas das comédias na constituição deste novo gênero de expressão sapiencial que são os 'Diálogos Socráticos'. Platão com certeza leu e estudou Epicarmo e Aristófanes, assim como tantos outros autores cujas obras circulavam em seu tempo. Se os livros eram raros e difíceis, isto não impediu Platão de despender recursos e esforços para obtê-los, como testemunhou Diógenes (3.9). E não teria sido Platão o genial filósofo e escritor que foi se não tivesse um particular ímpeto agonístico, que não o levaria propriamente a copiar, mas certamente a competir com seus êmulos. 


\section{Bibliografia}

O. Álvarez Salas (2007a), "Pseudepicharmea: alle origini di un corpus pseudepigrafo", Nova Tellus 25.1 117-153.

(2007b), "Epicarmo e Senófane: tessere di una polemica”, Nova Tellus 25.2 85-136.

(2007c) "I frammenti filosofici di Epicarmo: una rivisitazione critica", SIFC, ser. 4, 5.1 23-72.

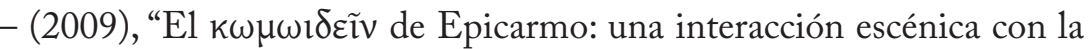
filosofia magno-greca" in D. García Pérez, ed. Teatro griego y tradición clásica. México, Universidad Nacional Autónoma de México 57-94.

L. Boulakia (1993), "Platon héritier d'Aristote" in H. Cherniss, ed. L'énigme de l'ancienne académie. Paris, Vrin.

L. Brisson (1992), "Diogène Laërce, 'Vies et doctrines des philosophes illustres', Livre III: Structure et contenu” in W. Haase, ed. $A N R W$, II 36.5. Berlin/Nova Iorque, Walter de Gruyter 3619-3760.

(1993), "Les accusations de plagiat lancées contre Platon" in M. Dixsaut, ed. Contre Platon, I. Paris, Vrin 339-356.

H. Cherniss (1945), The Riddle of the early Academy. San Francisco, University of California Press.

H. Diels - W. Kranz (51951), Die Fragmente der Vorsokratiker. Berlin, Weidmann (repr. 1996).

M.-O. Goulet-Cazé, ed. (1999), Diogène Laërce. Vies et doctrines des philosophes illustres. Paris, Librairie Générale Française.

R. D. Hicks (1925), Diogenes Laërtius. Lives of eminent philosophers. Trad., intr. e notas. London, W. Heinemann/New York, G. P. Putnam's Sons.

R. Kassel (1965), Aristotelis de arte poetica liber. Oxford, University Press.

R. Kassel - C. Austin (2001), Poetae Comici Graeci, I. Berlin, W. de Gruyter.

F. Nietzsche (1873), Die Philosophie im tragischen Zeitalter der Griechen. [versão digital da obra completa de Nietzsche editada por Giorgio Colli e Mazzino Montinari em: <http://www.nietzschesource.org/texts/ eKGWB/PHG >; acedido a 06/06/2013]

W. Rhys Roberts (21954), Aristotle. Rhetoric. New York, Modern Library. [publicado online por eBooks@Adelaide: <http://ebooks.adelaide.edu. $\mathrm{au} / \mathrm{a} /$ aristotle/a8rh/>; acedido a 06/06/2013].

D. Ross (1959a), Aristotelis Ars Rhetorica. Oxford, University Press. (1959b), Aristotelis Metaphysica. Oxford, University Press. 
Fernando Santoro

(1979), Aristotelis Fragmenta Selecta. Oxford, University Press.

L. Rossetti (2011), Le dialogue socratique. Paris, Les Belles Lettres. 